\title{
Porphyromonas gingivalis lipopolysaccharide enhances the proliferation of human periodontal ligament cells via upregulation of cyclin D1, cyclin A and cyclin B1
}

\author{
JIAJING LU ${ }^{1,2^{*}}$, YAJING HU ${ }^{1,3^{*}}$, ZHONGYUAN TANG ${ }^{1}$, CHENGFEI ZHANG $^{4}$, \\ LIJIAN JIN $^{5}$, MIN GU ${ }^{1}$ and YANQI YANG ${ }^{1}$
}

\begin{abstract}
${ }^{1}$ Division of Paediatric Dentistry and Orthodontics, Faculty of Dentistry, The University of Hong Kong, Hong Kong SAR 999077; ${ }^{2}$ Department of Orthodontics, School of Medical Technology, Taizhou Polytechnic College, Taizhou, Jiangsu 225300; ${ }^{3}$ Department of Cariology and Endodontology, Peking University School and Hospital of Stomatology and National Clinical Research Center for Oral Diseases and National Engineering Laboratory for Digital and Material Technology of Stomatology and Beijing Key Laboratory of Digital Stomatology, Beijing 100081; ${ }^{4}$ Division of Restorative Dental Sciences, Faculty of Dentistry, The University of Hong Kong; ${ }^{5}$ Division of Periodontology and Implant Dentistry, Faculty of Dentistry, The University of Hong Kong, Hong Kong SAR 999077, P.R. China
\end{abstract}

Received April 15, 2020; Accepted September 23, 2021

DOI: $10.3892 /$ etm.2021.10925

\begin{abstract}
Human periodontal ligament cells (hPDLCs) play a notable role in periodontal tissue homeostasis and regeneration. However, the effect of Porphyromonas gingivalis lipopolysaccharide ( $P g$-LPS) on the proliferation of hPDLCs remains unclear. The present study investigated the effects of $P g$-LPS on the proliferation profile of hPDLCs, and the involvement of cyclins and cyclin-dependent kinases in the process. hPDLCs were treated with $P g$-LPS, and cell proliferation and cycle were detected using Cell Counting Kit- 8 assays and flow cytometry. The mRNA expression levels of the cyclins and cyclin-dependent kinases (CDKs), including cyclins A, B1, D1 and D2 and CDK1, 2 and 4, were detected using reverse transcription-quantitative PCR. The protein expression levels of cyclins A, B1 and D1 were analysed using western blotting. The proliferation of hPDLCs was significantly increased after
\end{abstract}

Correspondence to: Dr Yanqi Yang, Division of Paediatric Dentistry and Orthodontics, Faculty of Dentistry, The University of Hong Kong, 34 Hospital Road, Hong Kong SAR 999077, P.R. China E-mail: yangyanq@hku.hk

*Contributed equally

Abbreviations: hPDLCs, human periodontal ligament cells; $P g$, Porphyromonas gingivalis; LPS, lipopolysaccharide; CCK-8, Cell Counting Kit-8; CDK, cyclin-dependent kinase; SPF, S-phase fraction; PDL, periodontal ligament; $\alpha$-MEM, modified Eagle's medium $\alpha$; RT-qPCR, reverse transcription-quantitative PCR; WB, western blotting; ANOVA, analysis of variance

Key words: Porphyromonas gingivalis, lipopolysaccharide, human periodontal ligament cells, cell proliferation, cell cycle treatment with $P g$-LPS at the concentrations of $0.001,0.01$, $0.1,1$ and $10 \mu \mathrm{g} / \mathrm{ml}$ for 24,36 and $48 \mathrm{~h}$ compared with the cells cultured without LPS $(\mathrm{P}<0.01)$. The proliferation index of hPDLCs was significantly enhanced after treatment with $P g$-LPS (0.0001, 0.001, 0.01, 0.1, 1 and $10 \mu \mathrm{g} / \mathrm{ml})$ for $24 \mathrm{~h}$ $(\mathrm{P}<0.01)$. However, the $\mathrm{S}$-phase fraction (SPF) only significantly increased after treatment with $P g$-LPS at $0.01 \mu \mathrm{g} / \mathrm{ml}$ for $24 \mathrm{~h}(\mathrm{P}<0.05)$, while the $\mathrm{G}_{2} / \mathrm{M}$-phase fraction increased $(P<0.01)$ and the $G_{0} / G_{1}$-phase fraction decreased $(P<0.01)$ compared with the controls. The proliferation index and SPF increased, peaked at $24 \mathrm{~h}$ and then decreased at $48 \mathrm{~h}$ in both $P g$-LPS-stimulated and control groups. Notably, $P g$-LPS significantly upregulated the expression levels of cyclins D1, $\mathrm{A}$ and B1 after $24 \mathrm{~h}$ compared with those in the controls. Overall, the present study indicated that $P g$-LPS may enhance the proliferation of hPDLCs, potentially through upregulation of cyclins D1, A and B1.

\section{Introduction}

Periodontal ligaments (PDL) connect the cementum to the alveolar bone and provide mechanical support to the periodontium (1). Human periodontal ligament cells (hPDLCs), largely composed of fibroblasts, are involved in PDL homeostasis and regeneration (2). The proliferation of hPDLCs may be required for the ability of the PDL to maintain a normal cell population and space under physiological conditions $(3,4)$. Cell proliferation is known to be activated by injury to the PDL, such as infection or overload force $(5,6)$. Therefore, the proliferation capacity of hPDLCs may be needed for the renewal and repair of the PDL.

Proliferation is controlled by cell cycle progression, which is a complex and stepwise process. Cyclins and cyclin-dependent kinases $(\mathrm{CDKs})$ are the predominant proteins that regulate the progression of the cell cycle. Cyclin D1 plays a notable role in $\mathrm{G}_{1}$ phase progression of the cell cycle via CDK4 activation (7). 
Cyclin D2 and cyclin A bind and activate CDK2, appearing in the $\mathrm{G}_{1} / \mathrm{S}$ and $\mathrm{S}$ phases $(8,9)$. Cyclin $\mathrm{B} 1$, in partnership with $\mathrm{CDK} 1$, is associated with the transition from the $\mathrm{G}_{2}$ phase to mitosis (10).

Porphyromonas gingivalis $(\mathrm{Pg})$ is a major periodontal pathogen whose lipopolysaccharide (LPS) induces the production of inflammatory cytokines, such as IL-1 $\beta,-6$, -8 and TNF- $\alpha$ (11-14). $P g$-LPS has been identified as an important contributor to periodontal inflammation, destruction and alveolar bone resorption (11,15-17). Numerous studies that investigated the interactions between $P g$-LPS and hPDLCs have demonstrated that $P g$-LPS can promote the immuno-inflammatory response of hPDLCs (16-18). Cell proliferation and inflammatory cytokine release are the two major inflammatory responses observed in this setting $(11,16,17)$. Given that pathological alterations caused by inflammatory insults can impact the regenerative capacities of hPDLCs, the mechanism of how LPS affects the proliferation of hPDLCs needs to be investigated. However, the impact of $P g$-LPS on hPDLC proliferation has not been clearly resolved and remains a debated subject. Yu et al (19) reported that LPS-induced inflammation inhibits cell proliferation. By contrast, studies by Kato et al (11) and Takemura et al (20) have suggested that $P g$-LPS promotes cell proliferation and induces pro-inflammatory cytokines. At present, to the best of our knowledge, there are few reports on the role of CDKs and cyclins in $P g$-LPS-induced inflammation, and the effects of $P g$-LPS on the cell cycle in the process of cell proliferation remain unclear. Therefore, the present study aimed to investigate the effects of $P g$-LPS on the proliferation of hPDLCs and regulation of the cell cycle.

\section{Materials and methods}

Culture of hPDLCs. Ethical approval for the present study was granted by the Institutional Review Board of the University of Hong Kong/Hospital Authority Hong Kong West Cluster (approval no. IRB UW13-120; Hong Kong, China). hPDLCs were isolated from the non-decayed, healthy teeth of three donors (two females aged 13 and 15 years old separately; one male aged 14 years old) who had undergone premolar extraction for orthodontic treatment at the Division of Paediatric Dentistry and Orthodontics in The Faculty of Dentistry, The University of Hong Kong from 10th January 2017 to 31st December 2018. Written consent to use the samples in scientific research was signed by the parents or legal guardians of the donors. The PDL tissues of the root were scraped and collected from the middle third of the premolar root surfaces to avoid contamination by cells derived from the gingiva and dental germ. The primary hPDLCs were cultured in modified Eagle's medium- $\alpha$ ( $\alpha$-MEM) containing $10 \%$ foetal bovine serum (HyClone; Cytiva) and $1 \%$ antibiotic solution $(100 \mathrm{U} / \mathrm{ml}$ penicillin and $100 \mu \mathrm{g} / \mathrm{ml}$ streptomycin) at $37^{\circ} \mathrm{C}$ in a humidified $5 \% \mathrm{CO}_{2}$ atmosphere. After achieving $80 \%$ confluence, cells were detached by treatment with $0.25 \%$ trypsin (Thermo Fisher Scientific, Inc.) and sub-cultured in fresh $\alpha$-MEM. The hPDLCs were characterised by immunocytochemical staining for vimentin and cytokeratin. The 3rd to 5th passages of the hPDLCs were used as the test (treated with $P g$-LPS) and control groups (without $P g$-LPS). The hPDLCs were synchronised in serum-free $\alpha$-MEM culture medium at $37^{\circ} \mathrm{C}$ for $24 \mathrm{~h}$. After serum starvation, the cells in the test and control groups were synchronised to the same stages of the cell cycle. This was based on previous studies demonstrating that serum starvation can arrest cells at the $G_{0} / G_{1}$ phase with high efficiency and no toxic effects $(5,21-24)$.

Cell viability and proliferation detection using cell counting kit-8 (CCK-8) assay. The hPDLCs were seeded into 96-well plates at $5 \times 10^{3}$ cells/well. After serum starvation, the cells were treated with $P g$-LPS (InvivoGen) at various concentrations $(0.0001,0.001,0.01,0.1,1$ and $10 \mu \mathrm{g} / \mathrm{ml})$ in the medium of $\alpha$-MEM containing $10 \%$ FBS for different durations $(0,6,12$, $18,24,36$ and $48 \mathrm{~h}$, respectively) at $37^{\circ} \mathrm{C}$ in vitro. Afterwards, $10 \mu 1$ CCK-8 solution (APExBIO Technology LLC) was added to each well of the plates. After incubation for $4 \mathrm{~h}$ at $37^{\circ} \mathrm{C}$, the plates were measured for absorbance at $450 \mathrm{~nm}$ using a microplate reader (Molecular Devices, LLC).

Flow cytometry for cell proliferation and cell cycle analysis. The dose- and time-dependent effects of $P g$-LPS were assessed separately by flow cytometry to monitor cell proliferation and cell cycle. To test the dose-dependent effects, hPDLCs were seeded into six-well plates at a density of $1.2 \times 10^{5}$ cells/well. After serum starvation, the cells were treated with $P g$-LPS at various concentrations $(0.0001,0.001$, $0.01,0.1,1$ and $10 \mu \mathrm{g} / \mathrm{ml}$ ) for $24 \mathrm{~h}$ at $37^{\circ} \mathrm{C}$ in vitro. To investigate the time-dependent effects, hPDLCs were seeded into six-well plates at a density of $0.6 \times 10^{5}$ cells/well. After serum starvation, the cells were stimulated with the appropriate concentration (based on the previous result) of $P g$-LPS for different durations $(0,6,12,18,24,36$ and $48 \mathrm{~h})$ at $37^{\circ} \mathrm{C}$ in vitro. Cells were harvested by trypsinisation, washed twice with ice-cold phosphate-buffered saline (PBS) and fixed in 70\% ethanol on ice for $15 \mathrm{~min}$. After the ethanol was washed out with PBS, the cells were re-suspended in $500 \mu 1$ DNA staining solution containing $50 \mu \mathrm{g} / \mathrm{ml}$ propidium iodide (Invitrogen; Thermo Fisher Scientific, Inc.), $0.05 \%$ Triton X-100 and $0.1 \% \mathrm{mg} / \mathrm{ml}$ RNase A in PBS. The samples were kept in the dark at $37^{\circ} \mathrm{C}$ for $40 \mathrm{~min}$. A FACSVerse flow cytometer (BD Biosciences) acquired 10,000 events for each sample, and the percentage of cells in the $G_{0} / G_{1}, S$ and $G_{2} / M$ phases of the cell cycle were determined using FlowJo software (version 10.0.7; Tree Star, Inc.). The proliferation index and S-phase fraction (SPF) were analysed using flow cytometry. The formulae used to calculate the above were as follows (25): Proliferation index $(\%)=\left[\left(\mathrm{S}+\mathrm{G}_{2} / \mathrm{M}\right) /\left(\mathrm{G}_{0} / \mathrm{G}_{1}+\mathrm{S}+\mathrm{G}_{2} / \mathrm{M}\right)\right] \times 100 \%$; SPF $(\%)=\left[\mathrm{S} /\left(\mathrm{G}_{0} / \mathrm{G}_{1}+\mathrm{S}+\mathrm{G}_{2} / \mathrm{M}\right)\right] \times 100 \% ; \mathrm{G}_{0} / \mathrm{G}_{1}$-phase fraction $(\%)=\left[\left(\mathrm{G}_{0} / \mathrm{G}_{1}\right) /\left(\mathrm{G}_{0} / \mathrm{G}_{1}+\mathrm{S}+\mathrm{G}_{2} / \mathrm{M}\right)\right] \times 100 \% ; \mathrm{G}_{2} / \mathrm{M}$-phase fraction $(\%)=\left[\left(\mathrm{G}_{2} / \mathrm{M}\right) /\left(\mathrm{G}_{0} / \mathrm{G}_{1}+\mathrm{S}+\mathrm{G}_{2} / \mathrm{M}\right)\right] \times 100 \%$.

Detection of genes via reverse transcription-quantitative PCR $(R T-q P C R)$. A RT-qPCR assay was carried out to analyse the mRNA expression of genes associated with different stages of proliferation. After hPDLCs were stimulated with $0.01 \mu \mathrm{g} / \mathrm{ml}$ $P g$-LPS for 18 or $24 \mathrm{~h}$, the mRNA expression levels of cyclins A, B1, D1, D2 and CDK1, 2 and 4 were detected by RT-qPCR. The sequences of the primers used are listed in Table I. Total RNA was immediately extracted from cells using TRIzol ${ }^{\circledR}$ reagent (Invitrogen; Thermo Fisher Scientific, Inc.) and then 
Table I. Primer sequences used in reverse transcription-quantitative PCR.

\begin{tabular}{lll}
\hline Gene name & \multicolumn{1}{c}{ Forward sequence $\left(5^{\prime}-3^{\prime}\right)$} & \multicolumn{1}{c}{ Reverse sequence $\left(5^{\prime}-3^{\prime}\right)$} \\
\hline Cyclin A & GCCTTTCATTTAGCACTC & TGAAGGTCCATGAGACAA \\
Cyclin B1 & GGAAACATGAGAGCCATCCT & TTCTGCATGAACCGATCAAT \\
Cyclin D1 & CAAACAGATCATCCGCAAAC & GCGTGTGAGGCGGTAGT \\
CDK1 & TGAAACTGCTCGCACTTG & ATGGTAGATCCCGGCTTATT \\
CDK2 & CAGAAACAAGTTGACGGGAGA & GACATCCAGCAGCTTGACAATA \\
CDK4 & ACAGCTACCAGATGGCACTTACA & CAAAGATACAGCCAACACTCCAC \\
Cyclin D2 & GTGTGATGCCATATCAAGTCC & TCGCATACACTGATCATGC \\
GAPDH & TCCCTGAGCTGAACGGGAAG & GGAGGAGTGGGTGTCGCTGT
\end{tabular}

CDK, cyclin-dependent kinase.

reverse transcribed to cDNA using SuperScript III Reverse Transcriptase (Invitrogen; Thermo Fisher Scientific, Inc.) in accordance with the manufacturer's instructions. qPCR was then performed using Power SYBR ${ }^{\circledR}$-Green PCR Master Mix (Applied Biosystems; Thermo Fisher Scientific, Inc.). GAPDH was used as the housekeeping gene for the internal control. The following thermocycling conditions were used for qPCR: Initial denaturation at $95^{\circ} \mathrm{C}$ for $10 \mathrm{~min}$, followed by 40 cycles of denaturation at $95^{\circ} \mathrm{C}$ for $15 \mathrm{sec}$ and annealing and extension at $60^{\circ} \mathrm{C}$ for $1 \mathrm{~min}$. The relative mRNA expression levels were quantified using the $2^{-\Delta \Delta \mathrm{Cq}}$ method (26) and normalized to the internal reference gene GAPDH.

Detection of proteins by western blotting (WB). After

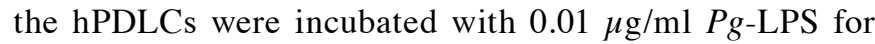
$24 \mathrm{~h}$, the cells were washed with cold PBS and lysed using a RIPA buffer (50 mM Tris; $\mathrm{pH}, 8.0 ; 150 \mathrm{mM} \mathrm{NaCl} ; 5 \mathrm{mM}$ EDTA, pH 8.0; $0.8 \%$ Triton $\mathrm{X}-100$ ) containing $1 \%$ protease inhibitor. Protein concentrations were determined using the bicinchoninic acid protein assay. Equal quantities of protein extracts $(30 \mu \mathrm{g} /$ lane) were separated via $10 \%$ SDS-PAGE. After transferring the proteins to PVDF membranes. The membranes were blocked for $1 \mathrm{~h}$ at room temperature with $5 \%$ non-fat milk in TBST $(10 \mathrm{mM}$ Tris, $100 \mathrm{mM} \mathrm{NaCl}$ and $0.1 \%$ Tween-20), after which they were probed overnight at $4^{\circ} \mathrm{C}$ with primary antibodies against cyclin $\mathrm{A}$ (1:500; cat. no. sc596; Santa Cruz Biotechnology, Inc.), cyclin B1 (1:500; cat. no. sc245; Santa Cruz Biotechnology, Inc.), cyclin D1 (1:1,000; cat. no. ab134175; Abcam) and $\beta$-actin $(1: 1,000$; cat. no. 8457; Cell Signaling Technology, Inc.). The membranes were washed with TBST and incubated with HRP-conjugated anti-IgG secondary antibodies (anti-rabbit IgG-HRP-linked antibody, 1:3,000; cat. no. cst7074; Cell Signaling Technology, Inc.; anti-mouse IgG-HRP-linked antibody, 1:3,000; cat. no. sc2055; Santa Cruz Biotechnology, Inc.) at room temperature for $2 \mathrm{~h}$. After washing, the blots were developed with enhanced chemiluminescence (WesternBright ${ }^{\circledR}$ ECL HRP substrate; Advansta, Inc.) and exposed to X-ray film (Kodak). The densities of western blotting bands were measured by Quantity One 4.6.9 software (Bio-Rad Laboratories, Inc.).

Statistical analysis. Statistical analysis was carried out using SPSS 19.0 software (IBM Corp.). A one-way analysis of variance (ANOVA) and Tukey's post hoc test were conducted for the data of flow cytometry and WB. A two-way ANOVA followed by Bonferroni test was performed for the CCK-8 and RT-qPCR data. All data were expressed as the mean \pm standard deviation from four independent experiments. $\mathrm{P}<0.05$ was considered to indicate a statistically significant difference.

\section{Results}

Cell viability and proliferation detection by CCK-8 assay. As presented in Fig. 1A, the hPDLCs were stimulated with $P g$-LPS at different concentrations (0.0001, 0.001, 0.01, 0.1, 1 and $10 \mu \mathrm{g} / \mathrm{ml})$ for various durations $(6,12,18,24,36$ and $48 \mathrm{~h})$ in vitro. The results showed that $P g$-LPS could not inhibit the cell viability of hPDLCs. The proliferation of hPDLCs was significantly enhanced in the culture medium at concentrations of 1 and $10 \mu \mathrm{g} / \mathrm{ml} P g$-LPS for $6(\mathrm{P}<0.05)$ and $18 \mathrm{~h}(\mathrm{P}<0.01)$ compared with the cells cultured without LPS. $P g$-LPS at the concentrations of $0.001,0.01,0.1,1$ and $10 \mu \mathrm{g} / \mathrm{ml}$ for 24,36 and $48 \mathrm{~h}$ significantly promoted the proliferation of hPDLCs compared with controls $(\mathrm{P}<0.01)$. The proliferation of hPDLCs was also significantly increased with $P g$-LPS at the concentration of $0.0001 \mu \mathrm{g} / \mathrm{ml}$ for $48 \mathrm{~h}$ compared with the cells cultured without LPS $(\mathrm{P}<0.01)$. These results suggested that $P g$-LPS could not inhibit the cell viability of hPDLCs. Instead, $P g$-LPS can increase hPDLC proliferation.

Cell proliferation and cell cycle analysis by flow cytometry. After serum starvation for $24 \mathrm{~h}$, the majority of cells were at the $\mathrm{G}_{0} / \mathrm{G}_{1}$ stage and few were in the $S$ or $G_{2} / \mathrm{M}$ phases of the cell cycle (Fig. S1). To assess the dose-dependent effect of Pg-LPS, hPDLCs were cultured with different concentrations of LPS (0.0001,0.001,0.01,0.1, 1 and $10 \mu \mathrm{g} / \mathrm{ml})$; the proliferation index of these treated cells was significantly enhanced compared with cells cultured without LPS $(\mathrm{P}<0.01)$, while there were no significant differences among the groups stimulated with $P g$-LPS at all concentrations tested (Fig. 1B). However, the SPF was only significantly increased with $P g$-LPS at a concentration of $0.01 \mu \mathrm{g} / \mathrm{ml}(\mathrm{P}<0.05)$, compared with cells cultured without LPS (Figs. 1B and S2). As presented in Figs. 2 and S3, when hPDLCs were incubated with $0.01 \mu \mathrm{g} / \mathrm{ml} \mathrm{Pg-LPS} \mathrm{for} 24 \mathrm{~h}$, the $\mathrm{G}_{2} / \mathrm{M}$-phase fraction of the hPDLCs was higher compared with that in the control group $(P<0.01)$, whereas the $G_{0} / G_{1}$-phase 

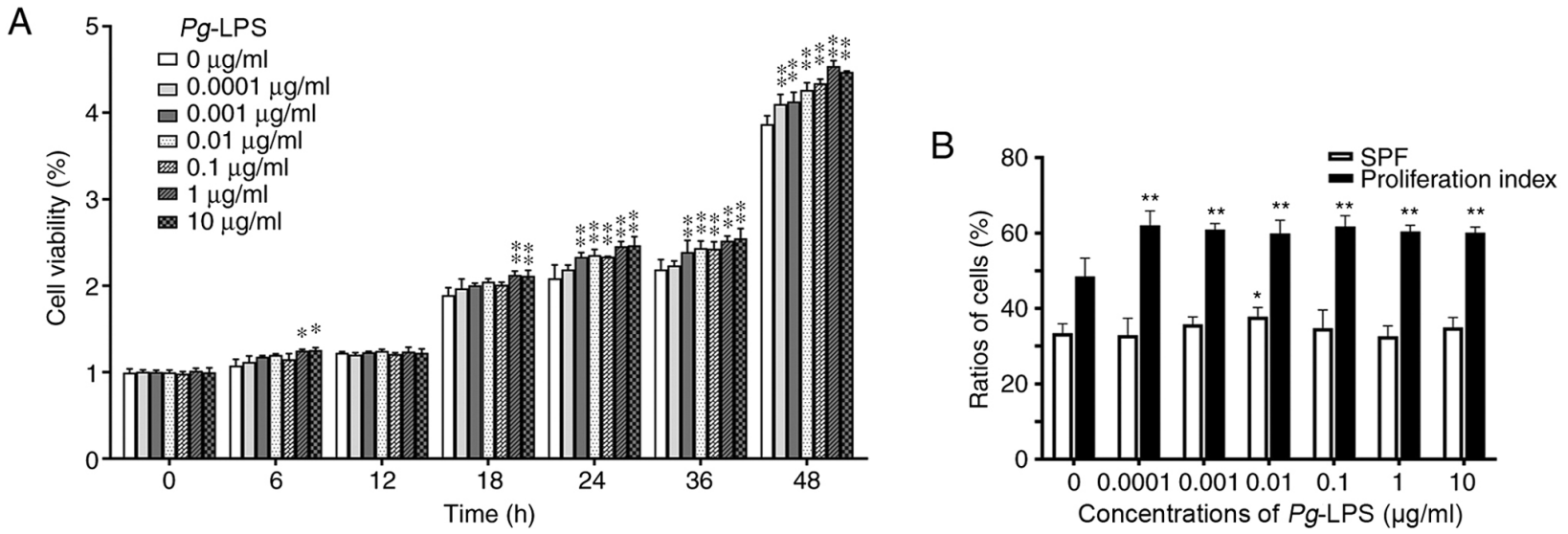

Figure 1. Effects of $P g$-LPS on the proliferation and cell cycle of hPDLCs. (A) Cell viability and proliferation detected using Cell Counting Kit-8 assay. Proliferation of hPDLCs was significantly enhanced in culture medium at the concentrations of 1 and $10 \mu \mathrm{g} / \mathrm{ml} P g-L P S$ compared with the cells cultured without LPS at 6 and $18 \mathrm{~h}$. Pg-LPS at the concentrations of $0.001,0.01,0.1,1$ and $10 \mu \mathrm{g} / \mathrm{ml}$ for 24,36 and $48 \mathrm{~h}$ significantly promoted the proliferation of hPDLCs compared with controls. The proliferation of hPDLCs was also significantly increased with $P g$-LPS at the concentration of $0.0001 \mu \mathrm{g} / \mathrm{ml}$ for $48 \mathrm{~h}$ compared with the cells cultured without LPS. (B) Cell proliferation and cell cycle analysis using flow cytometry. After treatment with different concentrations of $P g$-LPS $(0.0001,0.001,0.01,0.1,1$ and $10 \mu \mathrm{g} / \mathrm{ml})$ for $24 \mathrm{~h}$, the proliferation index of hPDLCs was significantly enhanced at concentrations ranging from $0.0001-10 \mu \mathrm{g} / \mathrm{ml}$, but the SPF only increased significantly at $0.01 \mu \mathrm{g} / \mathrm{ml}$ compared with that of cells without $\mathrm{LPS} .{ }^{*} \mathrm{P}<0.05,{ }^{* *} \mathrm{P}<0.01 \mathrm{vs}$. control group $(0 \mu \mathrm{g} / \mathrm{ml}$ $P g$-LPS) at each time point. Pg, Porphyromonas gingivalis; LPS, lipopolysaccharide; hPDLCs, human periodontal ligament cells; SPF, S-phase fraction.

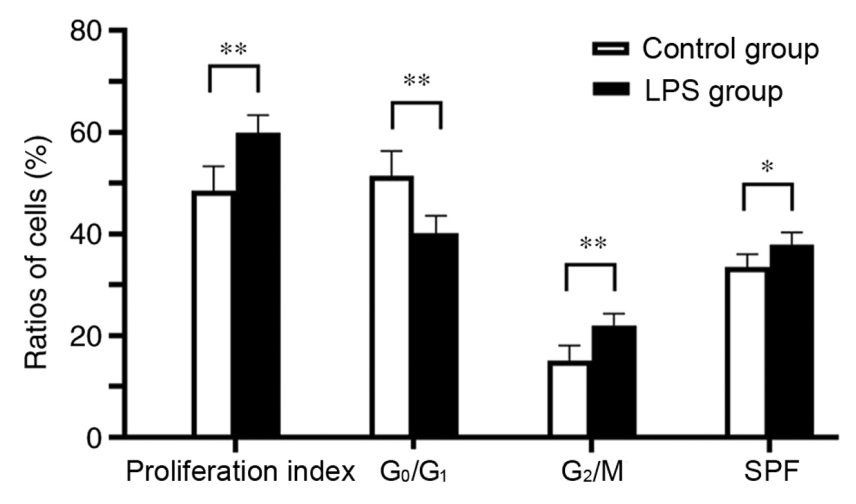

Figure 2. Effects of $0.01 \mu \mathrm{g} / \mathrm{ml} P g$-LPS on the proliferation index, the $\mathrm{G}_{0} / \mathrm{G}_{1}$-phase fraction, the $\mathrm{G}_{2} / \mathrm{M}$-phase fraction and SPF of hPDLCs. When hPDLCs were incubated with $0.01 \mu \mathrm{g} / \mathrm{ml} P g$-LPS for $24 \mathrm{~h}$, the proliferation index, SPF and $\mathrm{G}_{2} / \mathrm{M}$-phase fraction of hPDLCs were higher compared with the control group, whereas the $\mathrm{G}_{0} / \mathrm{G}_{1}$-phase fraction was lower. ${ }^{*} \mathrm{P}<0.05,{ }^{* *} \mathrm{P}<0.01$. Pg, Porphyromonas gingivalis; LPS, lipopolysaccharide hPDLCs, human periodontal ligament cells; SPF, S-phase fraction.

fraction was lower $(\mathrm{P}<0.01)$. Figs. 3 and $\mathrm{S} 4$ present the data for time-dependent effects. Both the proliferation index and SPF of the hPDLCs increased, reached a peak at $24 \mathrm{~h}$ and then decreased from 24 to $48 \mathrm{~h}$ in both the $P g$-LPS-stimulated and control groups. The proliferation index and SPF of hPDLCs were significantly increased after treatment with $P g$-LPS at 24 h compared with the cells cultured without LPS $(\mathrm{P}<0.01$ and $\mathrm{P}<0.05$, respectively), while they were significantly decreased after treatment with $P g$-LPS for 36 h compared with the cells cultured without LPS ( $\mathrm{P}<0.01$ and $\mathrm{P}<0.05$, respectively). There were no significant differences between $P g$-LPS-stimulated and control groups at $0,6,12,18$ and $48 \mathrm{~h}$. These results suggest that changes in PI and SPF were not dose-dependent, but were time-dependent.

mRNA expression levels of cyclins and CDKs in hPDLCs treated with Pg-LPS. The mRNA expression levels of cyclin A and cyclin D1 were significantly increased in the LPS-treated hPDLCs at 18 and $24 \mathrm{~h}$ compared with their control groups at the same time point $(\mathrm{P}<0.01)$, and the levels of cyclin $\mathrm{B} 1$ were also increased at $24 \mathrm{~h}(\mathrm{P}<0.01$; Fig. 4). There were no significant differences in CDK1, CDK 2 and CDK 4 mRNA expression levels at 18 and $24 \mathrm{~h}$ between the LPS-treated and control groups at the same time points (Fig. 4). By tracking the trends of change, the levels of cyclin A, cyclin B1, CDK1 and cyclin D2 in the LPS-treated group were revealed to have risen sharply at $24 \mathrm{~h}$ compared with those at $18 \mathrm{~h}$, whereas that of cyclin D1 decreased ( $\mathrm{P}<0.01$; Fig. 4). The expression levels of cyclin A, cyclin B1, CDK1 and CDK2 in the control group were higher at $24 \mathrm{~h}$ compared with those at $18 \mathrm{~h}(\mathrm{P}<0.05$; Fig. 4). These findings suggest that $P g$-LPS can mainly promote the mRNA expression levels of cyclins D1, A and B1.

Cyclin protein expression in hPDLCs treated with Pg-LPS. hPDLCs were incubated in the presence or absence of $0.01 \mu \mathrm{g} / \mathrm{ml}$ $P g$-LPS. After $24 \mathrm{~h}$ of treatment, the protein expression levels of cyclins A, B1 and D1 were analysed using western blotting. Total cell lysates were normalised to $\beta$-actin. The levels of cyclin B1 and cyclin D1 in the LPS-treated groups significantly increased after $24 \mathrm{~h}$ compared with control groups at the same time point $(\mathrm{P}<0.05$ and $\mathrm{P}<0.01$, respectively; Fig. 5). These results were in concordance with the mRNA expression levels. There were no significant differences in the expression levels of cyclin A between the control and LPS group. These results revealed that $P g$-LPS can upregulate the protein expression levels of cyclins Dland B1.

\section{Discussion}

The results of the present study indicated that high concentrations of $P g$-LPS (1 and $10 \mu \mathrm{g} / \mathrm{ml})$ stimulated the proliferation of hPDLCs at early stages $(6$ and $18 \mathrm{~h})$, and that low concentrations of $P g$-LPS $(0.001,0.01,0.1,1$ and $10 \mu \mathrm{g} / \mathrm{ml})$ stimulated the proliferation of hPDLCs at later stages (24, 36 and $48 \mathrm{~h}$ ). 

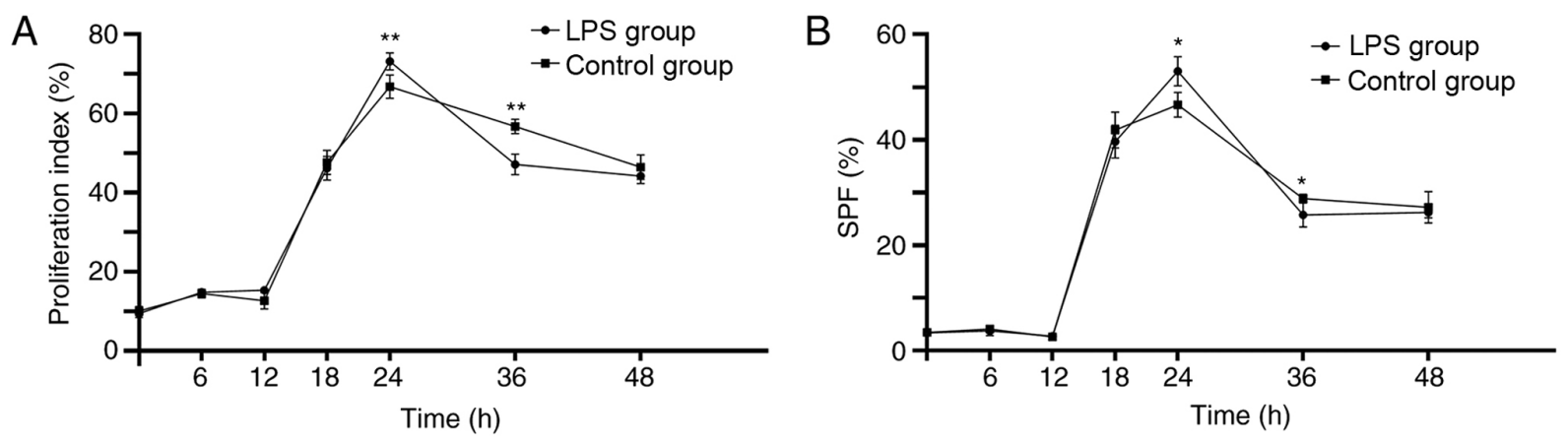

Figure 3. Changes of the proliferation index and SPF in hPDLCs induced by $0.01 \mu \mathrm{g} / \mathrm{ml} P g$-LPS for $48 \mathrm{~h}$. (A) Proliferation index and (B) SPF of hPDLCs increased, reached a peak at $24 \mathrm{~h}$ and then reduced from 24 to $48 \mathrm{~h}$ in $P g$-LPS-stimulated and control groups. ${ }^{*} \mathrm{P}<0.05,{ }^{* *} \mathrm{P}<0.01$ vs. control group at each time point. SPF, S-phase fraction; hPDLCs, human periodontal ligament cells; Pg, Porphyromonas gingivalis; LPS, lipopolysaccharide.

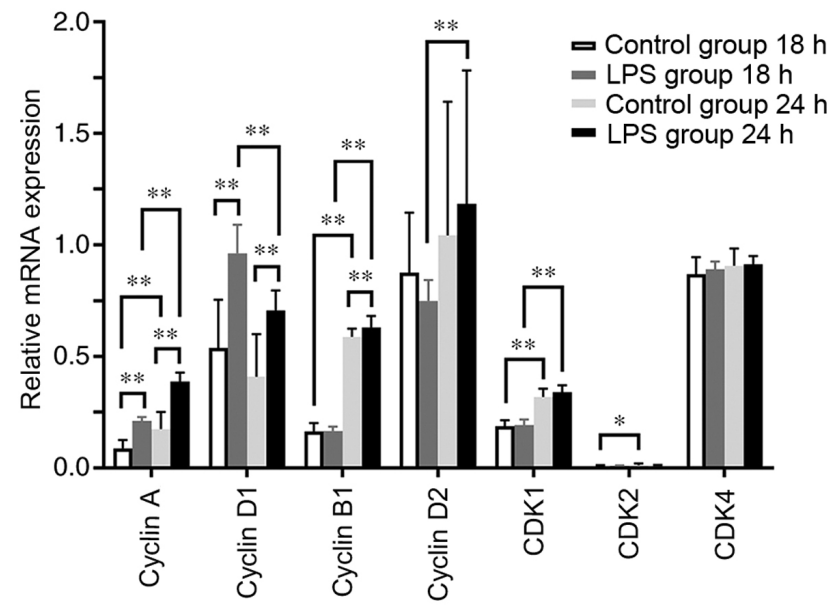

Figure 4. mRNA expression levels of cyclins A, B1, D1 and D2, and CDK1, 2 and 4 in hPDLCs treated with or without $0.01 \mu \mathrm{g} / \mathrm{ml} P g$-LPS at 18 and $24 \mathrm{~h}$. mRNA levels of cyclin A and cyclin D1 were significantly increased in the LPS-treated group at $18 \mathrm{~h}$ compared with those in the control group. mRNA levels of cyclins A, D1 and B1 were significantly increased in the LPS-treated group at $24 \mathrm{~h}$ compared with those in the control group. mRNA levels of cyclin A, cyclin B1, CDK1 and CDK2 in the control group were higher at $24 \mathrm{~h}$ compared with at $18 \mathrm{~h}$. mRNA levels of cyclin A, cyclin B1, cyclin D2 and CDK1 in the LPS-treated group rose sharply, whereas that of cyclin D1 fell from $18 \mathrm{~h}$ to $24 \mathrm{~h} .{ }^{*} \mathrm{P}<0.05,{ }^{* *} \mathrm{P}<0.01$. CDK, cyclin-dependent kinase; hPDLCs, human periodontal ligament cells; Pg, Porphyromonas gingivalis; LPS, lipopolysaccharide.

Moreover, $P g$-LPS at a concentration of $0.01 \mu \mathrm{g} / \mathrm{ml}$ prominently increased the proliferation of hPDLCs by affecting the $\mathrm{G}_{1}, \mathrm{~S}$ and $\mathrm{G}_{2} / \mathrm{M}$ phases. A number of studies have reported different results concerning the effects of LPS on the proliferation of hPDLCs. Jönsson et al (27) demonstrated that PDL cell proliferation is unaffected by stimulation for $72 \mathrm{~h}$ with a high concentration $(10 \mu \mathrm{g} / \mathrm{ml})$ of Escherichia coli LPS. Huang et al (28) reported that stimulation with $P g$-LPS (0.01, $0.1 \mu \mathrm{g} / \mathrm{ml}$ ) for either 3 or 5 days has no effect on PDL cell proliferation. Jung et al (29) also demonstrated similar results when treating cells with $P g$-LPS at different concentrations $(0.1,0.5$, $1,5,10$ and $20 \mu \mathrm{g} / \mathrm{ml}$ ) for 7 days. By contrast, other studies have indicated that treatment with $P g$-LPS at lower concentrations such as 0.01 and $0.1 \mu \mathrm{g} / \mathrm{ml}$ stimulates the proliferation of hPDLCs on day 3 (30), whereas high concentrations of LPS, such as 1 (28), 10 and $100 \mu \mathrm{g} / \mathrm{ml}(30)$, have been demonstrated inhibit the proliferation of hPDLCs.

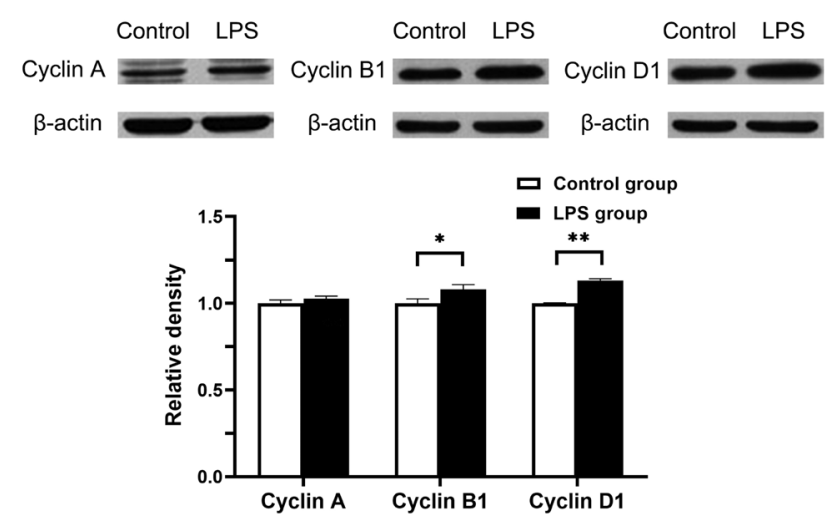

Figure 5. Protein expression levels of cyclins A, B1 and D1 in hPDLCs incubated in the presence or absence of $0.01 \mu \mathrm{g} / \mathrm{ml} \mathrm{Pg}$-LPS for $24 \mathrm{~h}$ and assessed using western blotting. Protein levels of cyclin B1 and cyclin D1 in the LPS-treated group significantly increased compared with those in the control group. ${ }^{*} \mathrm{P}<0.05,{ }^{* *} \mathrm{P}<0.01$. Pg, Porphyromonas gingivalis; LPS, lipopolysaccharide.

These aforementioned findings highlight differences in both the dose- and time-dependent effects of $P g$-LPS on the proliferation of hPDLCs. These contradictory results may be due to several reasons. First, hPDLCs in culture consist of several subpopulations (31). Second, there is a large amount of inter-individual heterogeneity in the responses of hPDLCs to $P g$-LPS (32). Third, the properties of hPDLCs may change with different passages (33). Fourth, the proliferation capability of hPDLCs is a function of the patient's age and health status (23). Fifth, these results depend on certain characteristics of hPDLCs, the chemical structures of LPS and a number of culture environmental factors, including primary cell separation methods, culture medium composition, oxygen concentration, culture time and other physical or chemical stimulation (34). Finally, in the majority of the aforementioned studies, cell proliferation was detected using an MTT assay (28-30). However, using quantitative measurements, such as the CCK- 8 assay, which is reported to be more stable and sensitive than MTT, improves the quality of results $(35,36)$.

In the present study, the 3rd to 5th passages of hPDLCs from young patients with good oral health were selected to eliminate the influence of ageing or diseases on proliferative ability (5,37). $P g$-LPS was used instead of $E$. coli LPS as $P g$ is a major periodontal pathogen that is capable of promoting cell 
proliferation and inflammatory cytokine production $(5,18)$. The present study detected both dose- and time-dependent effects using CCK-8 assay and flow cytometry to monitor cell proliferation and cell cycle.

As the cell cycle progresses, the preparatory $\mathrm{G}_{0} / \mathrm{G}_{1}$ phase ensures that everything is ready for DNA synthesis, after which DNA replication occurs during the $S$ phase (38). The $\mathrm{G}_{2} / \mathrm{M}$ phase is the nuclear fission stage, which focuses on orderly division of the cell into two daughter cells (39). Proliferation index and SPF are two factors of flow cytometry indicative of cell proliferation activity. They provide an approximation of the growth fraction and usually represent the velocity of cell division (40). The present study revealed that the proliferation index of hPDLCs increased significantly after treatment with $P g$-LPS $(0.001,0.01,0.1,1$ and $10 \mu \mathrm{g} / \mathrm{ml})$ for $24 \mathrm{~h}$ which was consistent with the results of CCK- 8 assay. However, there were no significant differences in the proliferation indices of hPDLCs among the groups stimulated with Pg-LPS at different concentrations $(0.0001,0.001,0.01,0.1,1$ and $10 \mu \mathrm{g} / \mathrm{ml})$. The SPF of hPDLCs only significantly increased when treated with $P g$-LPS at a concentration of $0.01 \mu \mathrm{g} / \mathrm{ml}$, whilst there were no significant differences after treatment with $P g$-LPS at the other concentrations $(0.0001,0.001,0.1$, 1 and $10 \mu \mathrm{g} / \mathrm{ml}$ ) compared with cells cultured without LPS. These results indicated that changes in the proliferation index and SPF were not dose-dependent. After the hPDLCs were stimulated with $0.01 \mu \mathrm{g} / \mathrm{ml} P g$-LPS for $24 \mathrm{~h}$, both the SPF and $\mathrm{G}_{2} / \mathrm{M}$-phase fraction were increased compared with those in the control group, whereas the $\mathrm{G}_{0} / \mathrm{G}_{1}$-phase fraction was significantly decreased. This suggested that $P g$-LPS enhanced the proliferation of hPDLCs by affecting both the $S$ and $\mathrm{G}_{2} / \mathrm{M}$ phases, while simultaneously reducing the proportion of cells in the $\mathrm{G}_{0} / \mathrm{G}_{1}$ phase.

The cell cycle is a complex process that is needed for the proliferation of cells. CDKs and cyclins are central to this process. Extensive work on gene knockout mouse models of cell cycle regulators has revealed compensatory mechanisms that regulate the interactions among cyclins and CDKs $(41,42)$. In addition, CDK2 has been revealed to be dispensable in the regulation of the mitotic cell cycle, as both CDK4 and CDK1 can cover for its functions (43). In the present study, the results of western blotting demonstrated that $P g$-LPS treatment increased the expression levels of cyclin D1 and cyclin B1, but not of cyclin A. This implied that the CDK4/cyclin D1 and $\mathrm{CDK} 1 /$ cyclin $\mathrm{B} 1$ complexes, as potential master regulators, may compensate for the function of the CDK2/cyclin A complex in cell cycle control upon exposure to $P g$-LPS. In the current study, the mRNA expression levels were consistent with those of protein expression for cyclin D1 and cyclin B1, but the cyclin A mRNA and protein expression levels were not concomitant. The inconsistency between cyclin A mRNA and protein expression levels may arise from several factors. First, the relationship between mRNA and protein expression levels is not strictly linear, as different regulatory mechanisms, such as gene transcription, post-transcriptional regulation, translation and protein modification, act on the synthesized mRNA and protein (44). Second, transcription and translation can be regulated in a spatiotemporal manner, and protein expression in known to lag behind mRNA transcription (45). Therefore, protein expression levels may not concur with mRNA transcription levels at a given time point. Third, the detection sensitivities are different for RT-qPCR and western blotting, with RT-qPCR having increased sensitivity. Overall, the results of RT-qPCR and western blotting analyses confirmed that $P g$-LPS was required for proliferation and acted by upregulating cyclin D1 and cyclin B1, which were involved in the $\mathrm{G}_{1}$ and $\mathrm{G}_{2} / \mathrm{M}$ phases, respectively.

Upon further investigating the time dependency of cell proliferation after exposure to $P g$-LPS, the present study revealed that $P g$-LPS significantly augmented the proliferation index and SPF of hPDLCs at the 24-h time point and significantly reduced both at the $36-\mathrm{h}$ time point but not at the other time points $(6,12,18$ or $48 \mathrm{~h})$. The proliferation of hPDLCs, as indicated by SPF and proliferation index, indicated the same trends in change for both the test and control groups, suggesting that $P g$-LPS did not change the overall time-dependency. Both the proliferation index and SPF of hPDLCs gradually increased, peaked at $24 \mathrm{~h}$ and then decreased from 24 to $48 \mathrm{~h}$ in both the $P g$-LPS-stimulated and control groups. Maintaining the proper incubation period is therefore critical for in vitro studies involving hPDLCs. The present study demonstrated that when control hPDLCs (without $P g$-LPS) were incubated for durations of 18 to $24 \mathrm{~h}$, cyclin A, cyclin B1, CDK1 and CDK2 significantly increased. When hPDLCs in the test group (treated with $0.01 \mu \mathrm{g} / \mathrm{ml} P g$-LPS) were incubated for the same durations, cyclin D2 levels also rose significantly and cyclin D1 levels fell. These observations may help explain why $P g$-LPS significantly augmented the proliferation index and SPF of hPDLCs at the $24 \mathrm{~h}$ time point but not at the $18 \mathrm{~h}$ time point, and why, when progressing from 18 to $24 \mathrm{~h}$, cyclin D2 increased to accelerate the $G_{1} / S$ transition and cyclin D1 decreased to slowed down $\mathrm{G}_{1}$ progression. Changes that occur over longer durations will require further investigations in the future.

Currently, the intrinsic mechanisms by which Pg-LPS affects cell proliferation and regulates the cell cycle are unknown. Numerous studies have suggested that $P g$-LPS produces pro-inflammatory cytokines mainly through the Toll-like receptor 4 pathway, which influences cell proliferation $(5,19)$. However, the effect of $P g$-LPS on the cell cycle and the concentration of $P g$-LPS that affects hPDLCs proliferation are still matters of debate $(18,46-48)$. The present study demonstrated that $P g$-LPS promoted the proliferation of hPDLCs and that $P g$-LPS prominently affected the $\mathrm{G}_{1}, \mathrm{~S}$ and $\mathrm{G}_{2} / \mathrm{M}$ phases at a concentration of $0.01 \mu \mathrm{g} / \mathrm{ml}$. $P g$-LPS was also demonstrated to likely affect the cell cycle through the actions of cyclin D1 and cyclin B1. However, the exact role of cyclin A in the cell cycle control is not yet clear as the result of inconsistencies between the RT-qPCR and WB data in the present study.

In summary, $P g$-LPS may significantly stimulate the proliferation of hPDLCs through the upregulation of cyclins D1, A and B1. The mechanism of $P g$-LPS on the proliferation and cell cycle regulation of hPDLCs remains unclear, and further studies are required. The results from the current study only address the short-term effects of $P g$-LPS on the proliferation of hPDLCs. However, periodontal disease is a chronic inflammatory condition that can occur due to multiple and complex factors. Hence, more investigations conducted over longer durations are warranted to further understand periodontal pathogenesis and devise more effective therapeutic strategies. 


\section{Acknowledgements}

The authors would like to acknowledge Mr Tong Wai Man (flow cytometry and reverse transcription-quantitative PCR technical support), Ms Yu Ching Lam (cell culture technical support) and Ms Tong Hoi Yee (western blotting technical support), all from Centralized Research Laboratory, Faculty of Dentistry, The University of Hong Kong (Hong Kong, China).

\section{Funding}

The project was supported by the General Research Fund from the Research Grants Council of Hong Kong (grant no. 17106619).

\section{Availability of data and materials}

The datasets used and/or analysed during the current study are available from the corresponding author on reasonable request.

\section{Authors' contributions}

YY, CZ and LJ made substantial contributions to the overall structural design of the study, methodology and data analysis. JL, YH and ZT performed the experiments. JL detected the cell proliferation and cell cycle by flow cytometry and analysed mRNA expression levels of the cyclins and CDKs by RT-qPCR. YH performed the western blotting of the cyclins. $\mathrm{ZT}$ and MG were major contributors in the CCK- 8 assay for cell proliferation. JL and YH analyzed the data, drafted and revised the manuscript under the guidance of $\mathrm{CZ}, \mathrm{LJ}$ and $\mathrm{YY}$. JL and YH confirmed the authenticity of all the raw data. All authors have read and approved the final manuscript.

\section{Ethics approval and consent to participate}

Ethical approval for the present study was granted by the Institutional Review Board of the University of Hong Kong/Hospital Authority Hong Kong West Cluster (approval no. IRB UW13-120; Hong Kong, China).

\section{Patient consent for publication}

Not applicable.

\section{Competing interests}

The authors declare that they have no competing interests.

\section{References}

1. Garant PR: Collagen resorption by fibroblasts. A theory of fibroblastic maintenance of the periodontal ligament. J Periodontol 47: 380-390, 1976

2. Hughes FJ, Ghuman M and Talal A: Periodontal regeneration: A challenge for the tissue engineer? Proc Inst Mech Eng H 224: $1345-1358,2010$

3. Lekic P and McCulloch C: Periodontal ligament cell populations: The central role of fibroblasts in creating a unique tissue. Anat Rec 245: 327-341, 1996.

4. McCulloch CA and Melcher AH: Continuous labelling of the periodontal ligament of mice. J Periodontal Res 18: 231-241, 1983.
5. Liu J, Tang X, Li C, Pan C, Li Q, Geng F and Pan Y: Porphyromonas gingivalis promotes the cell cycle and inflammatory cytokine production in periodontal ligament fibroblasts. Arch Oral Biol 60: 1153-1161, 2015.

6. Mabuchi R, Matsuzaka K and Shimono M: Cell proliferation and cell death in periodontal ligaments during orthodontic tooth movement. J Periodontal Res 37: 118-124, 2002.

7. Sherr CJ: G1 phase progression: Cycling on cue. Cell 79: 551-555, 1994.

8. Girard F, Strausfeld U, Fernandez A and Lamb NJ: Cyclin A is required for the onset of DNA replication in mammalian fibroblasts. Cell 67: 1169-1179, 1991.

9. Sweeney KJ, Sarcevic B, Sutherland RL and Musgrove EA: Cyclin D2 activates Cdk 2 in preference to Cdk4 in human breast epithelial cells. Oncogene 14: 1329-1340, 1997.

10. Takizawa CG and Morgan DO: Control of mitosis by changes in the subcellular location of cyclin-B1-Cdk1 and Cdc25C. Curr Opin Cell Biol 12: 658-665, 2000.

11. Kato H, Taguchi Y, Tominaga $K$, Umeda $M$ and Tanaka A: Porphyromonas gingivalis LPS inhibits osteoblastic differentiation and promotes pro-inflammatory cytokine production in human periodontal ligament stem cells. Arch Oral Biol 59: 167-175, 2014.

12. Morandini AC, Sipert CR, Gasparoto TH, Greghi SL, Passanezi E, Rezende ML, Sant'ana AP, Campanelli AP, Garlet GP and Santos CF: Differential production of macrophage inflammatory protein-1alpha, stromal-derived factor-1, and IL-6 by human cultured periodontal ligament and gingival fibroblasts challenged with lipopolysaccharide from $P$. gingivalis. J Periodontol 81: 310-317, 2010.

13. Pathirana RD, O'Brien-Simpson NM and Reynolds EC: Host immune responses to Porphyromonas gingivalis antigens. Periodontol 2000 52: 218-237, 2010.

14. Wada N, Maeda $\mathrm{H}$, Yoshimine $\mathrm{Y}$ and Akamine $\mathrm{A}$ : Lipopolysaccharide stimulates expression of osteoprotegerin and receptor activator of NF-kappa B ligand in periodontal ligament fibroblasts through the induction of interleukin-1 beta and tumor necrosis factor-alpha. Bone 35: 629-635, 2004.

15. Krajewski AC, Biessei J, Kunze M, Maersch S, Perabo L and Noack MJ: Influence of lipopolysaccharide and interleukin-6 on RANKL and OPG expression and release in human periodontal ligament cells. APMIS 117: 746-754, 2009.

16. Park YD, Kim YS, Jung YM, Lee SI, Lee YM, Bang JB and Kim EC: Porphyromonas gingivalis lipopolysaccharide regulates interleukin (IL)-17 and IL-23 expression via SIRT1 modulation in human periodontal ligament cells. Cytokine 60: 284-293, 2012.

17. Seo T, Cha S, Kim TI, Lee JS and Woo KM: Porphyromonas gingivalis-derived lipopolysaccharide-mediated activation of MAPK signaling regulates inflammatory response and differentiation in human periodontal ligament fibroblasts. J Microbiol 50: 311-319, 2012.

18. Yamaji Y, Kubota T, Sasaguri K, Sato S, Suzuki Y, Kumada H and Umemoto T: Inflammatory cytokine gene expression in human periodontal ligament fibroblasts stimulated with bacterial lipopolysaccharides. Infect Immun 63: 3576-3581, 1995.

19. Yu B, Li Q and Zhou M: LPS-induced upregulation of the TLR4 signaling pathway inhibits osteogenic differentiation of human periodontal ligament stem cells under inflammatory conditions. Int J Mol Med 43: 2341-2351, 2019.

20. Takemura A, Matsuda N, Kimura S, Fujiwara T, Nakagawa I and Hamada S: Porphyromonas gingivalis lipopolysaccharide modulates the responsiveness of human periodontal ligament fibroblasts to platelet-derived growth factor. J Periodontal Res 33: 400-407, 1998

21. Tong J, Sun D, Yang C, Wang Y, Sun S, Li Q, Bao J and Liu Y: Serum starvation and thymidine double blocking achieved efficient cell cycle synchronization and altered the expression of p27, p53, bcl-2 in canine breast cancer cells. Res Vet Sci 105: 10-14, 2016.

22. Khammanit R, Chantakru S, Kitiyanant Y and Saikhun J: Effect of serum starvation and chemical inhibitors on cell cycle synchronization of canine dermal fibroblasts. Theriogenology 70: 27-34, 2008.

23. Nishimura F, Terranova VP, Braithwaite M, Orman R, Ohyama H, Mineshiba J, Chou HH, Takashiba S and Murayama Y: Comparison of in vitro proliferative capacity of human periodontal ligament cells in juvenile and aged donors. Oral Dis 3: 162-166, 1997.

24. Liu F, Wu BL, Gao J, Huang X, Ma DD and Chen T: Effects of serum starvation on cell cycle synchronization in human dental pulp cells. Chin J Conserv Dent 21: 67-71, 2011. 
25. Mikami K, Haseba T and Ohno Y: Ethanol induces transient arrest of cell division (G2 + M block) followed by G0/G1 block: Dose effects of short- and longer-term ethanol exposure on cell cycle and cell functions. Alcohol Alcohol 32: 145-152, 1997.

26. Livak KJ and Schmittgen TD: Analysis of relative gene expression data using real-time quantitative PCR and the 2(-Delta Delta C(T)) method. Methods 25: 402-408, 2001.

27. Jönsson D, Nebel D, Bratthall G and Nilsson BO: LPS-induced MCP-1 and IL-6 production is not reversed by oestrogen in human periodontal ligament cells. Arch Oral Biol 53: 896-902, 2008.

28. Huang M, Yan F, Yao L, Li D, Zheng Y, Li Y and Lin M: Effects of cyclosporine A and Porphyromonas gingivalis-lipopolysaccharide on proliferation of human periodontal ligament fibroblasts in vitro. Chin J Stomatol Res 5: 470-476, 2011.

29. Jung IH, Lee DE, Yun JH, Cho AR, Kim CS, You YJ, Kim SJ and Choi SH: Anti-inflammatory effect of (-)-epigallocatechin-3-gallate on Porphyromonas gingivalis lipopolysaccharide-stimulated fibroblasts and stem cells derived from human periodontal ligament. J Periodontal Implant Sci 42: 185-195, 2012.

30. Zhang F, Wu Z, Wan L and Yuan N: Effects of lipopolysaccharides on proliferation and alkaline phosphatase activity of periodontal ligament cells. Chin J Conserv Dent 13: 27-29, 2003.

31. Jönsson D, Nebel D, Bratthall G and Nilsson BO: The human periodontal ligament cell: A fibroblast-like cell acting as an immune cell. J Periodontal Res 46: 153-157, 2011.

32. Scheres N,Laine ML, de Vries TJ,Everts V and van Winkelhoff AJ: Gingival and periodontal ligament fibroblasts differ in their inflammatory response to viable Porphyromonas gingivalis. J Periodontal Res 45: 262-270, 2010.

33. Itaya T, Kagami H, Okada K, Yamawaki A, Narita Y, Inoue M, Sumita Y and Ueda M: Characteristic changes of periodontal ligament-derived cells during passage. J Periodontal Res 44 425-433, 2009.

34. Jia L, Wen $\mathrm{Y}$ and $\mathrm{Xu} \mathrm{X}$ : Effects of culture conditions in vitro on the biological characteristics of periodontal ligament stem cells. Int J Stomatol 45: 255-260, 2018.

35. Tominaga $H$, Ishiyama $M$, Ohseto $F$, Sasamoto $K$, Hamamoto $T$ Suzuki K and Watanabe M: A water-soluble tetrazolium salt useful for colorimetric cell viability assay. Anal Commun 36: 47-50, 1999.

36. Failli A, Legitimo A, Orsini G, Castagna M, Spisni R, Miccoli P and Consolini R: Antiproliferative effects of 5-fluorouracil and oxaliplatin in colon cancer cell lines: Comparison of three different cytotoxicity assays. J Biol Regul Homeost Agents 27: 275-284, 2013

37. Shiba H, Nakanishi K, Sakata M, Fujita T, Uchida Y and Kurihara $\mathrm{H}$ : Effects of ageing on proliferative ability, and the expressions of secreted protein, acidic and rich in cysteine (SPARC) and osteoprotegerin (osteoclastogenesis inhibitory factor) in cultures of human periodontal ligament cells. Mech Ageing Dev 117: 69-77, 2000.
38. Masai H, Matsumoto S, You Z, Yoshizawa-Sugata N and Oda M: Eukaryotic chromosome DNA replication: Where, when, and how? Annu Rev Biochem 79: 89-130, 2010.

39. Schafer KA: The cell cycle: A review. Vet Pathol 35: 461-478, 1998.

40. Gray JW, Dolbeare F, Pallavicini MG, Beisker W and Waldman F: Cell cycle analysis using flow cytometry. Int J Radiat Biol Relat Stud Phys Chem Med 49: 237-255, 1986.

41. Malumbres M, Sotillo R, Santamaria D, Galan J, Cerezo A, Ortega S, Dubus P and Barbacid M: Mammalian cells cycle without the D-type cyclin-dependent kinases Cdk4 and Cdk6. Cell 118: 493-504, 2004

42. Kozar K, Ciemerych MA, Rebel VI, Shigematsu H,Zagozdzon A, Sicinska E, Geng Y, Yu Q, Bhattacharya S, Bronson RT, et al: Mouse development and cell proliferation in the absence of D-cyclins. Cell 118: 477-491, 2004.

43. Satyanarayana A and Kaldis P: Mammalian cell-cycle regulation: Several Cdks, numerous cyclins and diverse compensatory mechanisms. Oncogene 28: 2925-2939, 2009.

44. Mehra A, Lee KH and Hatzimanikatis V: Insights into the relation between mRNA and protein expression patterns: I. Theoretical considerations. Biotechnol Bioeng 84: 822-833, 2003.

45. Gedeon T and Bokes P: Delayed protein synthesis reduces the correlation between mRNA and protein fluctuations. Biophys J 103: 377-385, 2012.

46. Du A, Zhao S, Wan L, Liu T, Peng Z, Zhou Z, Liao Z and Fang H: MicroRNA expression profile of human periodontal ligament cells under the influence of Porphyromonas gingivalis LPS. J Cell Mol Med 20: 1329-1338, 2016.

47. Han Y, Wang F, Shao L, Huang P and Xu Y: LncRNA TUG1 mediates lipopolysaccharide-induced proliferative inhibition and apoptosis of human periodontal ligament cells by sponging miR-132. Acta Biochim Biophys Sin (Shanghai) 51: 1208-1215, 2019.

48. Francis M, Pandya M, Gopinathan G, Lyu H, Ma W, Foyle D, Nares $S$ and Luan X: Histone methylation mechanisms modulate the inflammatory response of periodontal ligament progenitors. Stem Cells Dev 28: 1015-1025, 2019.

This work is licensed under a Creative Commons Attribution-NonCommercial-NoDerivatives 4.0 International (CC BY-NC-ND 4.0) License. 